doi: 10.1111/imig. 12707

\title{
Foreign Labour Migration in Sarawak, East Malaysia
}

\author{
Linda Alfarero Lumayag*
}

\begin{abstract}
Foreign labour force participation in Sarawak is thirteen per cent (about 138,027) workers from Indonesia, Philippines, Myanmar, China and India, among others. This article attempts to describe the management of foreign labour employment in Sarawak. It also attempts to identify challenges and issues that current migration regulations have generated and which have impacted the society. Using the Filipino migrant workers as informants, a two-year period of fieldwork observation was conducted, using personal interviews and observations following the 'mobile ethnography approach'. While Sarawak maintains its immigration control as part of the State safety net, the interplay between state and federal laws engenders contradictions that may be detrimental to the people and to society. This article argues that the claimed autonomous position of Sarawak in regard to immigration is not equated to better labour migration management in relation to the federal government's approach to labour migration in Malaysia.
\end{abstract}

\section{INTRODUCTION}

Few studies have explored on the issue of international labour migration in Sarawak. Though there were studies conducted earlier, especially the works of Amarjit Kaur $(1995,2004,2014,2015)$ on the political-economic history of Malaysia, van Schendel (2005) on the illicit flows of trades in border communities; Majid-Cooke (1997) on land and plantation economy and De Jong et al. (2010) on trans-border governance between Indonesia and Malaysia, the issue of international labour migration has not been given centre stage in the migration discourse. More often topics like the federal-state relations are centred on electoral politics (Chin, 2014; 2019; Faizal, 2018; Mersat, 2017; Osman and Rhasaad, 2017) for example, political control and dominance of United Malays Nationalist Organisation (UMNO) and its umbrella party Barisan Nasional in the federal government until its eventful national electoral defeat in 2018. In this article, I pose this question: where does the difference lie in the management of labour migration between East Malaysia and West Malaysia, and how could this difference produce the same employment problems of foreign workers in Sarawak?

This article attempts to understand the issues surrounding managing labour migration in Sarawak, especially in relation to how foreign workers (or non-resident workers) are employed in the economy. Specifically, it describes some similarities and differences between the State and Federal regulations in the hiring, recruitment and employment of foreign labour. It also investigates how the

* Universiti Malaysia Sarawak 